\title{
Out of New Zealand: molecular identification of the highly invasive freshwater mollusk Potamopyrgus antipodarum (Gray, 1843) in South America
}

\author{
Gonzalo A Collado ${ }^{1,2}$
}

\begin{abstract}
Background: The New Zealand mud snail Potamopyrgus antipodarum (Gray, 1843) is among the most widespread non-indigenous mollusk in the world. Based on a comprehensive phylogenetic analysis, the invasion of this species to central Chile, which is also the first record of this species from South America, is reported.

Results: Molecular analysis identified four populations of $P$. antipodarum in central Chile, Parque O'Higgins and Estero La Dehesa in Santiago city, and Estero Consuelo and the Chalinga River in Salamanca, a town located in a different basin. No sequence divergence was found among populations in the cytochrome c oxidase subunit I (COI) gene. Morphological and reproductive evidence is in agreement with these findings.

Conclusions: This is the first record of $P$. antipodarum in the Neotropical region. All populations contained only females with embryos or juvenile snails in their brood pouches suggesting that they are viable and well established. It is important to prevent the spread of $P$. antipodarum to other localities in Chile and other South American countries.
\end{abstract}

Keywords: Biological invasions; Caenogastropoda; Chile; COI gene; Tateidae

\section{Background}

The widespread introduction of non-native species has been considered as one of the major threats to biodiversity (Lodge and Shrader-Frechette 2003). The mud snail Potamopyrgus antipodarum is a caenogastropod originated from New Zealand and adjacent islands (Winterbourn 1970, 1972). This snail has become among the most widespread non-indigenous aquatic invertebrates in the world (Butkus et al. 2012). Several transport methods have been reported as responsible for propagation of this global exotic species, which include both active and passive dispersal (Alonso and Castro-Diez 2008). This species has invaded brackish and freshwater habitats in several countries in Europe, Australia, Asia, and North America (e.g. Ponder 1988; Bowler 1991; Shimada and Urabe 2003; Radea et al. 2008; Butkus et al. 2012; Hamada et al. 2013).

\footnotetext{
Correspondence: gcollado@ubiobio.cl

'Departamento de Ciencias Básicas, Facultad de Ciencias, Universidad del Bío-Bío, Avda. Andrés Bello s/n, Casilla 447, Chillán, Chile

${ }^{2}$ Fundación Chile Natura, Santiago, Chile
}

Potamopyrgus antipodarum is a minute snail highly variable in size, shape and ornamentation. Adults range from 3 to $6 \mathrm{~mm}$ in length in USA, but they reach $11 \mathrm{~mm}$ in their native habitat (Richards 2002). Winterbourn (1970) reported considerable variation in the shell ornamentation of the species in its native range, even within a single population. Shell polymorphism in P. antipodarum would be influenced by environmental and genetics bases (Winterbourn 1970; Haase 2003). Recently, Butkus et al. (2012) reported regular (smooth) and carinate morphotypes from Lake Vilkokšnis, suggesting two independent invasion events. However, this should be taken with caution since the presence of a keel-like ridge can be a phenotypically plastic trait.

Potamopyrgus antipodarum is a generalist species, feeding on aquatic plants, green algae and detritus (Haynes and Taylor 1984), being able to tolerate a broad range of physicochemical aquatic conditions (Dorgelo 1987; Proctor et al. 2007; Poirier 2013). In the rivers of Wyoming, USA, the species dominates secondary production, even reaching 
one of the highest values of productivity ever reported for a stream invertebrate (Hall et al. 2006). Zaranko et al. (1997) reported its densities in Lake Ontario being as high as 5,600 snails per square meter, which is a value close to that found in native populations $\left(4,000 / \mathrm{m}^{2}\right.$, see Collier et al. 1998). However, in other invaded habitats, $P$. antipodarum can achieve densities as high as 500,000 snails per square meter (Hall et al. 2003; Richards 2002; Richards et al. 2001), and even more $\left(800,000 / \mathrm{m}^{2}\right.$, see Dorgelo 1987).

Because frequently there are no obvious morphological characters to distinguish different components of invertebrate fauna, DNA barcoding and molecular phylogenetic analysis are increasingly used to identify aquatic invaders in a variety of taxa (e.g. Geller et al. 1997; Facon et al. 2003; Albrecht et al. 2009; Duggan et al. 2012;
Porco et al. 2013; Wetterer 2014). In 2010, an investigation of the small freshwater gastropod of the superfamily Rissooidea Gray, 1847 sensu lato of Chile was initiated by the author, sampling snails from a number of locations. In a previous morphological work, Collado et al. (2011a) assigned snails from the Chalinga River and Estero Consuelo to the genus Heleobia Stimpson, 1865 following Biese $(1944,1947)$. Here, I perform a comprehensive phylogenetic analysis to evidence that these snails actually represent the non-native species $P$. antipodarum. I also report the occurrence of this species in other two watersheds from central Chile, Estero La Dehesa east of Santiago, and a spring located within the Parque O'Higgins, also in this city. Additionally, I evaluate the reproductive performance of populations studied.

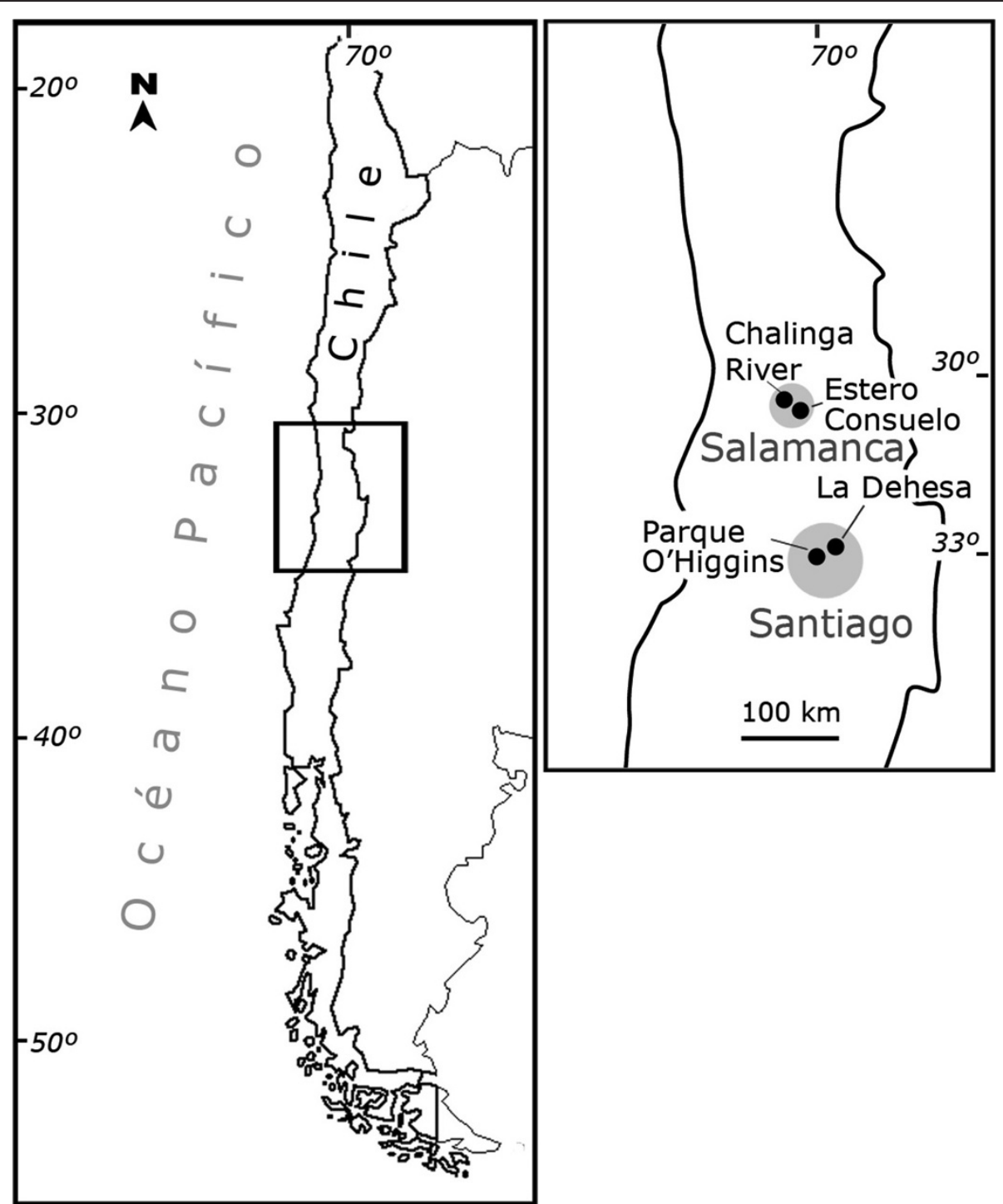

Figure 1 Sampling sites of Potamopyrgus antipodarum in central Chile (black dots). 


\section{Methods}

In this study, four localities in two regions from central Chile, Región de Coquimbo and Región Metropolitana, were sampled from prospective sites for snail collection (Figure 1). In Región de Coquimbo, two watersheds were sampled, both in the town of Salamanca, the Chalinga River ( $31^{\circ} 46^{\prime} 15.61^{\prime \prime} \mathrm{S}$; $\left.70^{\circ} 59^{\prime} 05.09^{\prime \prime} \mathrm{W}\right)$, which is a small, intermittent watercourse north of the town, and Estero Consuelo ( $31^{\circ} 46^{\prime} 48.61^{\prime \prime} \mathrm{S}$; $\left.70^{\circ} 57^{\prime} 37.33^{\prime \prime} \mathrm{W}\right)$, a stream east of the town. In Región Metropolitana, two watersheds were sampled in Santiago city; Estero La

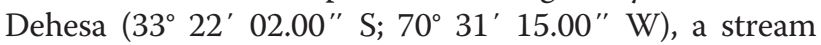
located in the eastern suburbs of the city, and Parque O'Higgins ( $33^{\circ} 28^{\prime} 06.22^{\prime \prime}$ S; $\left.70^{\circ} 39^{\prime} 38.31^{\prime \prime} \mathrm{W}\right)$, an urban park that offers recreation, fishing, and open green space to residents and whose southern section includes a spring that flows about $300 \mathrm{~m}$ into an small artificial lagoon. In this spring, $P$. antipodarum co-occur with a snail species of the genus Physa Draparnaud, 1801, platyhelminthes, and other invertebrates. The snails were obtained from macrophytes of the spring using a sieve and preserved in absolute ethanol prior to molecular and morphological analyses. The snails were photographed at the same magnification with a Motic SMZ168 Stereo Microscope (Motic, Richmond, BC, Canada) with a Moticam 2000 (Motic, Xiamen, China) integrated digital camera. The shell of adult snails was broken and the mantle tissue was removed to determine the sex by the presence/absence of a penis. In the case of the females, the oviduct wall was dissected to determine the presence of embryos or juveniles. The measurements of animals were performed under a stereo microscope. The author is authorized to the removal of animals from watersheds in Chile (Resolution $\mathrm{N}^{\circ} 3285$, Subsecretaria de Pesca y Acuicultura, Ministerio de Economía, Fomento y Turismo, República de Chile). Voucher specimens of $P$. antipodarum were deposited in the Colección Malacológica del Servicio Agrícola y Ganadero de Chile (CMSAG 3651 and 3652).

A small piece of tissue from the mantle and gill was cut off from the snails to extract genomic DNA using the cetyl trimethylammonium bromide (CTAB) method (Winnepennickx et al. 1993). A fragment of the mitochondrial gene, cytochrome $c$ oxidase subunit I (COI) was amplified by polymerase chain reaction (PCR) using the primers LCO1490 (5'-GGTCAACAAATCATAAA GATATTGG-3') and HCO2198 (5' ${ }^{\prime}$-TAAACTTCAGG GTGACCAAAAAATCA-3') (Folmer et al. 1994); PCR conditions were the same as those in Collado et al. (2011b). Amplified products were sequenced by Macrogen Inc., South Korea. The sequences were edited and aligned with BioEdit (Hall 2001) using default parameters. Phylogenetic analyses were performed using maximum parsimony (MP) and Bayesian inference (BI) methods. The MP analysis was carried out with the program PAUP* 4.0 (Swofford 2003) using a heuristic search with the tree bisection and reconnection branch swapping algorithm and the addition of random sequences. Character states were treated as unordered, assuming equal weight. The statistical confidence of the nodes was evaluated using 100

Table 1 Classification and GenBank accession numbers for the rissooidean taxa studied

\begin{tabular}{|c|c|c|c|}
\hline Family & Species & GenBank accession & Source \\
\hline Barleeiidae & Barleeia oldroydi (Bartsch 1920) & JX970602 & Wilke et al. (2013) \\
\hline Amnicolidae & Amnicola limosa (Say, 1817) & AF213348 & Wilke et al. (2000a) \\
\hline Assimineidae & Assiminea grayana Fleming, 1828 & HQ623170 & Wilke et al. (2013) \\
\hline Beddomeia group & Beddomeia paludinella (Reeve, 1857) & JX970603 & \\
\hline Bithyniidae & Bithynia tentaculata (Linnaeus, 1758) & JX970605 & \\
\hline Bythinellidae & Bythinella austriaca (Frauenfeld, 1856) & AF213349 & Wilke et al. (2000a) \\
\hline Iravadiidae & Clenchiella sp. & JX970606 & Wilke et al. (2013) \\
\hline Cochliopidae & Heleobops carrikeri Davis and McKee, 1989 & AF213347 & Wilke et al. (2000a) \\
\hline Falsicingulidae & Falsicingula athera Bartsch, 1936 & HQ623172 & Wilke et al. (2013) \\
\hline Hydrobiidae & Hydrobia acuta (Draparnaud, 1805) & AF278808 & Wilke et al. (2000b) \\
\hline Lithoglyphidae & Lithoglyphus naticoides (Pfeiffer, 1828) & AF367642 & Wilke et al. (2001) \\
\hline Moitessieriidae & Moitessieria cf. puteana Coutagne, 1883 & AF367635 & \\
\hline Pomatiopsidae s.s. & Pomatiopsis lapidaria (Say, 1817) & AF367636 & \\
\hline Rissooidae & Setia turriculata Monterosato, 1884 & AF253084 & Davis et al. (1998) \\
\hline Stenothyridae & Stenothyra cf. glabra A. Adams, 1861 & HQ623177 & Wilke et al. (2013) \\
\hline Tateidae & Tatea huonensis (Tenison-Woods, 1876) & JX970619 & Wilke et al. (2013) \\
\hline Hydrobiidae & Ascorhis tasmanica Martens, 1858 & AF129329 & Hershler et al. (1999) \\
\hline Truncatellidae & Geomelania inornata Chitty, 1853 & AF367629 & Wilke et al. (2001) \\
\hline
\end{tabular}


Table 2 GenBank accession numbers for the taxa studied of the family Tateidae

\begin{tabular}{|c|c|c|}
\hline Species & $\begin{array}{l}\text { GenBank } \\
\text { accession } \\
\text { number }\end{array}$ & Source \\
\hline Fluviopupa sp. & JX970615 & Wilke et al. (2013) \\
\hline Halopyrgus pupoides (Hutton, 1882) & JX970616 & \\
\hline $\begin{array}{l}\text { Hemistomia winstonefi } \\
\text { (Haase and Bouchet, 1998) }\end{array}$ & JX970617 & \\
\hline Obtusopyrgus alpines Haase, 2008 & AY631088 & \\
\hline Opacuincola delira Haase, 2008 & AY631090 & \\
\hline Potamolithus ribeirensis Pilsbry, 1911 & JX970618 & Wilke et al. (2013) \\
\hline \multirow{6}{*}{$\begin{array}{l}\text { Potamopyrgus antipodarum } \\
\text { (Gray, 1843) }\end{array}$} & EU573983 & Ponder et al. (2008) \\
\hline & $A B 703675$ & Hamada et al. (2013) \\
\hline & AB703676 & \\
\hline & AB703677 & \\
\hline & AY631101 & Haase (2005) \\
\hline & AY631102 & \\
\hline \multirow{2}{*}{$\begin{array}{l}\text { Potamopyrgus estuarinus } \\
\text { (Winterbourn, 1971) }\end{array}$} & AY631103 & \\
\hline & AY631104 & \\
\hline \multirow{2}{*}{$\begin{array}{l}\text { Potamopyrgus kaitunuparaoa } \\
\text { Haase, } 2008\end{array}$} & AY631105 & \\
\hline & AY631106 & \\
\hline $\begin{array}{l}\text { Potamopyrgus oppidanus } \\
\text { Haase, } 2008\end{array}$ & AY631112 & \\
\hline Sororipyrgus kutukutu Haase, 2008 & AY631108 & \\
\hline Catapyrgus matapango Haase, 2008 & AY631072 & \\
\hline Hadopyrgus ngataana Haase, 2008 & AY631073 & \\
\hline Leptopyrgus melbourni Haase, 2008 & AY631075 & \\
\hline Rakiurapyrgus cresswelli (Climo, 1974) & AY631081 & \\
\hline $\begin{array}{l}\text { Meridiopyrgus muaupoko } \\
\text { Haase, } 2008\end{array}$ & AY631083 & \\
\hline Paxillostium nanum Gardner, 1970 & AY631111 & \\
\hline Halopyrgus pagodulus Haase, 2008 & AY631113 & \\
\hline Tongapyrgus kohitatea Haase, 2008 & AY631124 & \\
\hline $\begin{array}{l}\text { Tatea huonensis } \\
\text { (Tenison-Woods, 1876) }\end{array}$ & JX970619 & Wilke et al. (2013) \\
\hline Tatea rufilabris (A. Adams, 1862) & EU151940 & Colgan and da Costa ${ }^{a}$ \\
\hline $\begin{array}{l}\text { Edgbastonia alanwillsi } \\
\text { Ponder et al. } 2008\end{array}$ & EU580440 & Ponder et al. (2008) \\
\hline \multirow[t]{4}{*}{ Spring from Parque O'Higgins } & KJ616603 & Present study \\
\hline & KJ616604 & Present study \\
\hline & KJ616605 & Present study \\
\hline & KJ616606 & Present study \\
\hline \multirow[t]{4}{*}{ Chalinga River } & KJ616607 & Present study \\
\hline & KJ616608 & Present study \\
\hline & KJ616609 & Present study \\
\hline & KJ616610 & Present study \\
\hline
\end{tabular}

Table 2 GenBank accession numbers for the taxa studied of the family Tateidae (Continued)

\begin{tabular}{lll}
\hline Estero Consuelo & KJ616611 & Present study \\
KJ616612 & Present study \\
KJ616613 & Present study \\
KJ616614 & Present study \\
Estero La Dehesa & KJ616615 & Present study \\
KJ616616 & Present study \\
KJ616617 & Present study \\
KJ616618 & Present study \\
\hline
\end{tabular}

anpublished data.

bootstrap pseudoreplicates (Felsenstein 1985). The BI was performed with MrBayes v. 3.1.2 (Ronquist and Huelsenbeck 2003) after selecting the best evolutionary model in jModelTest (Posada 2008). The analysis was run three times for 3 million generations, sampling trees every 1,000 generations and using a burn-in period of $10 \%$.

As Chilean rissooidean snails have been assigned to different families (Collado et al. 2011a), original sequences were aligned with sequences of snails obtained from GenBank covering a wide range of taxa within this superfamily (see Wilke et al. 2013) (Table 1). After ascertaining the family of the Chilean snails, original sequences were aligned with sequences of different genera within the particular family to determine the genus and species to which the snails belong, in this case P. antipodarum. Original sequences were deposited in GenBank (Table 2).

\section{Results}

The snails collected in central Chile have ovate to conical shell shape, smooth, with a deep suture, and with up to six whorls (Figure 2). The aperture is oval, sometimes thickened, and with a thin brown operculum. The external shell morphology of these snails is consistent with the drawings and photographs of $P$. antipodarum shown in other studies (Winterbourn 1970, 1972; Gangloff 1998; Butkus et al. 2012; Poirier 2013). All the snails examined in the present study were females. The largest snail belonged to the population from Estero La Dehesa (Table 3). The presence of embryos or juveniles in the breeding pouches was detected in every studied population (Figure 3). In a previous study, Collado and Méndez (2011) demonstrated that the species treated as Heleobia choapaensis (Biese, 1944) from Estero Consuelo was ovoviviparous.

A COI fragment of $639 \mathrm{bp}$ was amplified in the snail sampled in the present study. No sequence variation was found within the four populations. The MP and BI analyses indicated that these snails fell in a clade integrated by snails that belong to the family Tateidae Thiele, 1925 (Figure 4). In both analyses, the Tateidae node was highly supported. A subsequent phylogenetic analysis included 


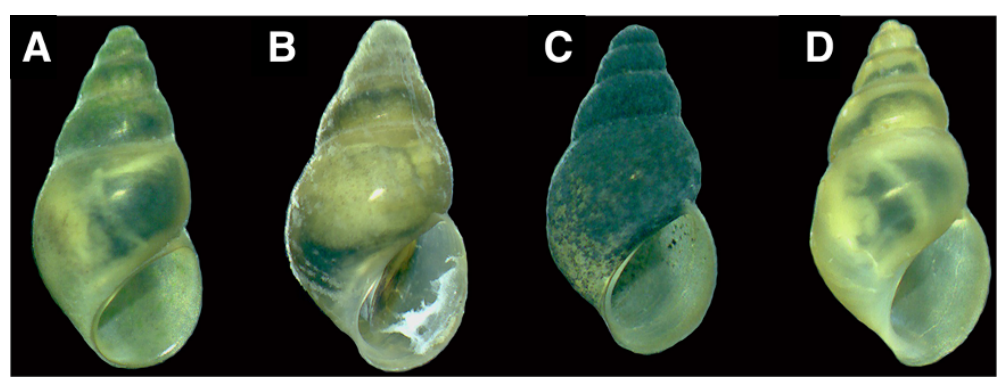

Figure 2 Living representative adult snails of Potamopyrgus antipodarum in central Chile. Shell length and shell width are given in millimeters. (A) Parque O'Higgins $(3.8 \times 2.1)$ (B) Estero La Dehesa $(4.0 \times 2.1)$. (C) Estero Consuelo $(2.9 \times 1.5)$. (D) Chalinga River $(2.9 \times 1.6)$.

20 species of this family (Table 2) using Ascorhis tasmanica as an outgroup (see also Wilke et al. 2013 for the sister group of the Tateidae). In this analysis, the matrix was composed of 638 nucleotide sites. The relationships among these species were well resolved by the MP and $\mathrm{BI}$ analyses (selected model: TPM2uf $+\mathrm{I}+\mathrm{G}$ ). Both analyses located the snails studied here within the genus Potamopyrgus (MP: 96\% bootstrap support), specifically within the clade composed by the sequences of the species $P$. antipodarum (MP: 100\% bootstrap support). The same systematic position was inferred in the BI analysis $(1.00$ posterior probability) (Figure 5).

The haplotype of the invader tateid snails from Chile was identical with the haplotype of the European invader from West India Dock, London (GenBank: EU573983) (Ponder et al. 2008), Chitose River in Japan (GenBank: AB703675) (Hamada et al. 2013), and those obtained in Lake Superior, USA (GenBank: GQ996433) and Lake Alexandrina, New Zealand (GenBank: GQ996432) (Neiman et al. 2010, personal communication).

\section{Discussion}

The morphological survey, reproductive features, and the COI gene markers data showed that the populations surveyed in central Chile belong to the highly invasive clonal snail $P$. antipodarum. Although several native hydrobioid species have been named or assigned to the genus Potamopyrgus Stimpson, 1865 on the South American continent (Pilsbry 1911, 1944, 1952; Doello Jurado 1916; Haas 1938, 1949, 1952; Lima and Pereira de Souza 1990), at

Table 3 Number of snails collected, and size of specimens used in the present study; all specimens collected were females

\begin{tabular}{llll}
\hline Locality & $\begin{array}{l}\text { Specimens } \\
\text { observed }\end{array}$ & $\begin{array}{l}\text { Shell size of the } \\
\text { smallest specimen } \\
\text { (length-wide) }\end{array}$ & $\begin{array}{l}\text { Shell size of the } \\
\text { largest specimen } \\
\text { (length-wide) }\end{array}$ \\
\hline Parque O'Higgins & 20 & $3.5 \times 1.7 \mathrm{~mm}$ & $4.4 \times 2.2 \mathrm{~mm}$ \\
Estero La Dehesa & 15 & $2.8 \times 1.5 \mathrm{~mm}$ & $5.1 \times 2.6 \mathrm{~mm}$ \\
Chalinga River & 39 & $2.7 \times 1.4 \mathrm{~mm}$ & $4.2 \times 1.9 \mathrm{~mm}$ \\
Estero Consuelo & 24 & $2.5 \times 1.3 \mathrm{~mm}$ & $4.4 \times 1.9 \mathrm{~mm}$ \\
\hline
\end{tabular}

present all of them are allocated in different genera (Gaillard 1973; Gaillard and de Castellanos 1976; Hershler and Thompson 1992; Wesselingh 2000; Pons da Silva 2003). Thus until now, there was no evidence of the presence of the genus Potamopyrgus neither in Chile nor any other South American country.

In the present study, only a single haplotype was identified in the four Chilean localities, although this may be not conclusive because only four snails were sequenced in each location. In North America, Dybdahl and Drown (2011) found four genotypes of $P$. antipodarum from the whole USA. Different haplotypes of this species were also identified in Japan as a consequence of more than one colonization event (Hamada et al. 2013). At present, it is impossible to know the origin and exact time of the arrival of $P$. antipodarum to Chile considering that the

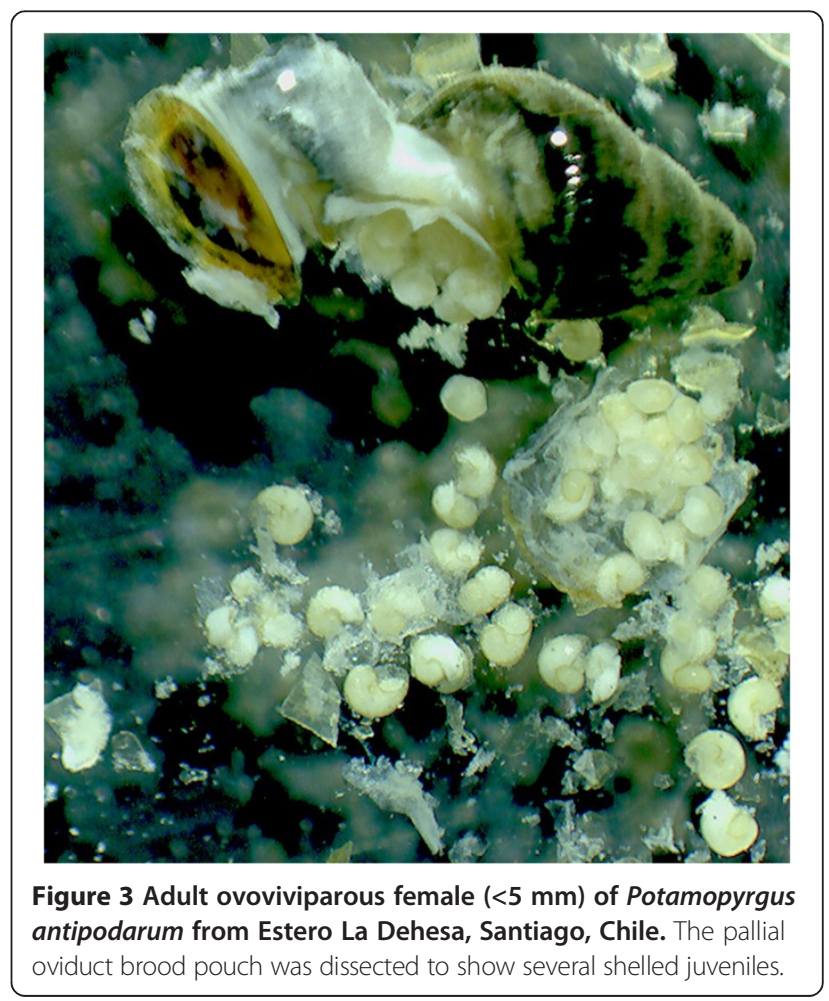




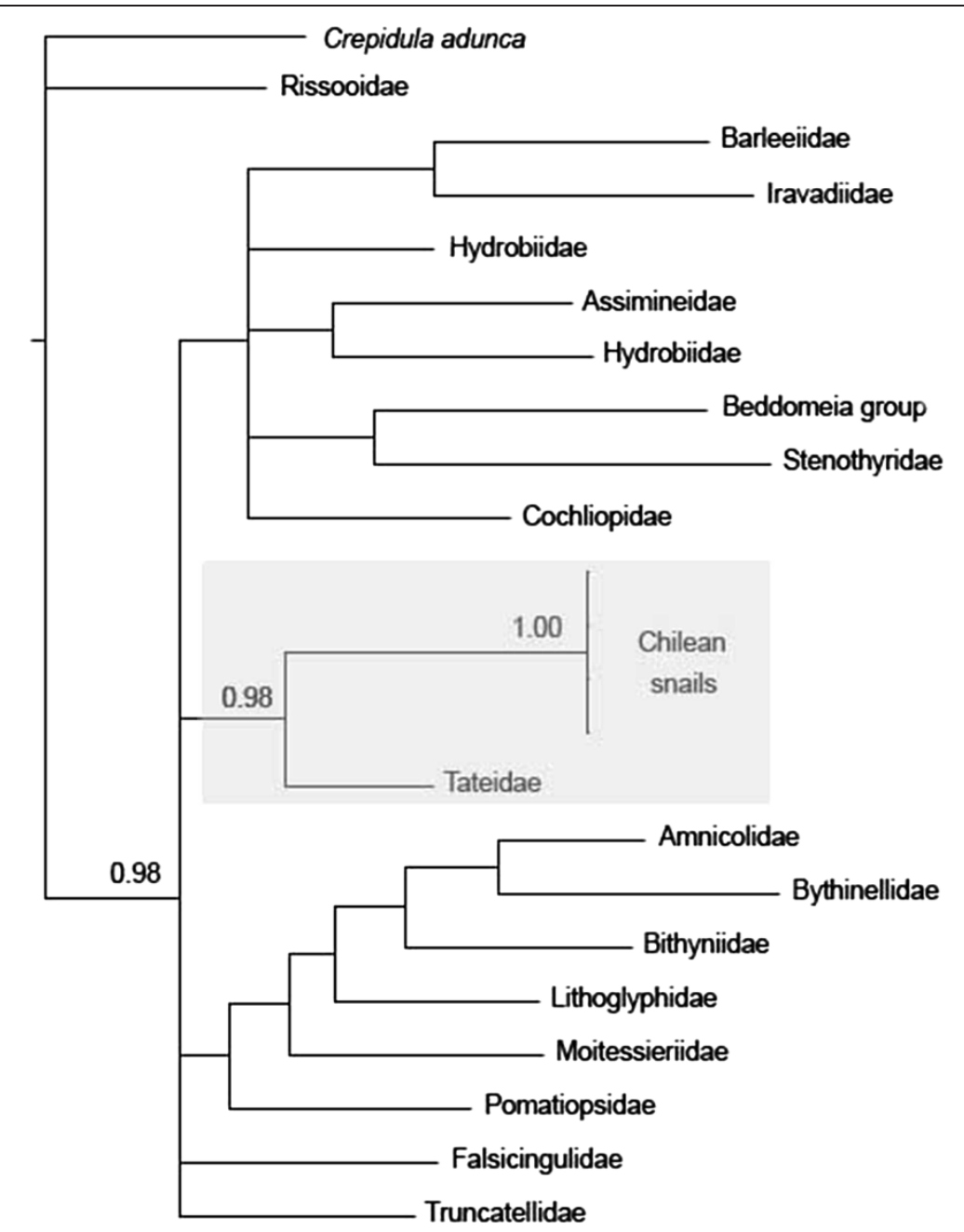

Figure 4 Bayesian consensus tree of rissooidean snails based on COI gene sequences. The phylogenetic position of the Chilean snails is shown in the gray box. The taxa represent the families (or family-level assignments) within the rissooidean (see Wilke et al. 2013). Numbers above the nodes indicate posterior probability values obtained in the BI (only values equal to or above 0.95 are shown). The outgroup in this analysis was chosen following Wilke et al. (2013).

same haplotype is found in Japan, England, New Zealand, and USA (Ponder et al. 2008; Neiman et al. 2010; Hamada et al. 2013, present study). A microsatellite analysis could reveal more informative results due to the higher mutation rates than $\mathrm{COI}$ gene.

It has been suggested that at high densities $P$. antipodarum may compete with native macroinvertebrates for food or space (Kerans et al. 2005) and alter the nutrient cycles, especially nitrogen and carbon (Hall et al. 2003), with significant effects on higher and lower trophic levels (Kerans et al. 2005). Potamopyrgus antipodarum is extremely abundant in the spring from Parque O'Higgins, where it reaches thousands of animals per square meter (unpublished data). The snails also are relatively abundant in the other localities, except in Estero La Dehesa, where in one hour of sampling using a sieve, only 15 snails were obtained. This, together with the observation of viable breeding snails and similar size range reported in other invaded regions, suggest that the populations of these animals are well established in central Chile. It is unknown whether the species is more widespread in this country.

Ovoviviparity seems to be an important factor for successful invasions. With this type of reproductive strategy (Winterbourn 1970; Ponder 1988), P. antipodarum females brood embryos in a brood pouch and release from 20 to 120 free crawling juveniles (Cheng and LeClair 2011). Native P. antipodarum populations contain both abundant parthenogenetic females and sexual females and males at a relatively lower proportion (Winterbourn 1970). However, non-native populations mostly consist of parthenogenetic females, males being rare or absent (Gangloff 1998; Butkus et al. 2012). Thus, colonization may have occurred from the introduction of a single female (Proctor et al. 2007; Cheng and LeClair 2011; 


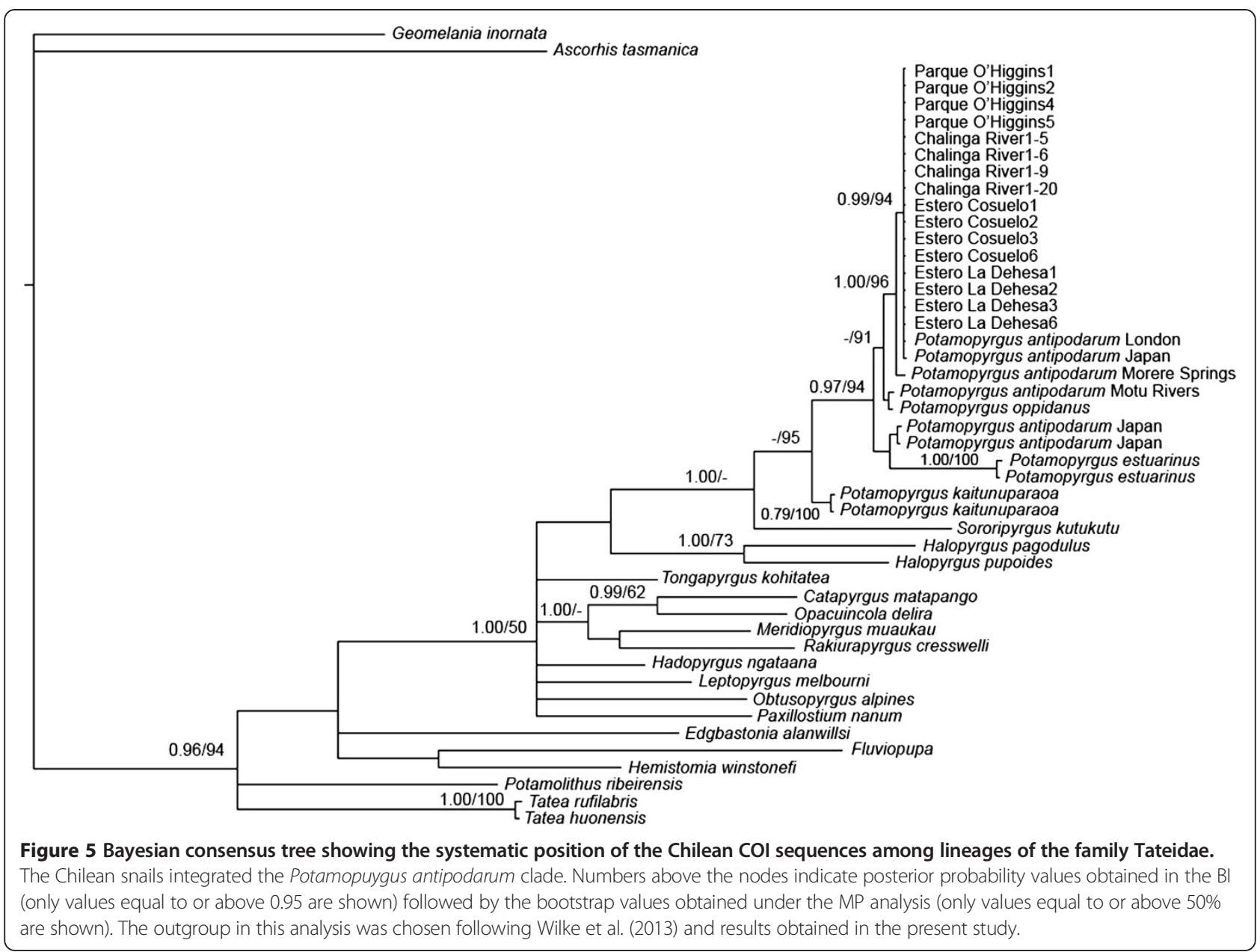

Poirier 2013). Like $P$. antipodarum, the exotic ovoviviparous snail Sinotaia quadrata (Benson 1842) (Viviparidae Gray, 1847) was also introduced into South America and is now established in Argentina (Ovando and Cuezzo 2012).

Potential natural vectors of $P$. antipodarum include fish, birds, water flow, and floating algae or macrophytes (Vareille-Morel 1983; Ribi 1986; Zaranko et al. 1997; Proctor et al. 2007). Regarding transport by animals, these snails can survive passage through the digestive system of fish and birds (Haynes et al. 1985; Ribi 1986). Non-natural vectors include ship ballast water, freshwater tanks, aquaculture products, aquatic ornamental plants, domestic livestock, firefighting machinery, recreational watercraft and trailers, transport of mud, and sport fishing equipment (Ribi 1986; Bowler 1991; Richards et al. 2001; Proctor et al. 2007; Ponder et al. 2008; Alonso and Castro-Diez 2008); it is unknown how the species came to Chile.

The NZ Mudsnail Management Plan Working Group in USA was established in 2003 to prevent and delay the spread of the introduced $P$. antipodarum to new areas into the United States (Proctor et al. 2007). Some of the objectives proposed were identify foci, pathways and vectors of $P$. antipodarum, develop methods of detecting new populations of this species and develop strategies to control introduced populations. In Chile, exotic freshwater snails have increased in recent times; the main route of introduction has probably been freshwater commercial aquarium trade (Jackson and Jackson 2009; Letelier et al. 2007). The procedures proposed by Proctor et al. (2007) may be implemented in Chile as a control measure against these species and $P$. antipodarum.

\section{Conclusions}

The phylogenetic analysis of COI gene supports the inclusion of the snail sequences from Parque O'Higgins, Estero La Dehesa, Estero Consuelo, and the Chalinga River in central Chile into the Potamopyrgus antipodarum lineage. Thus, the snails studied belong to the family Tateidae. In all locations, sexually mature females were found. Ecological studies are needed to understand the impact of this invasive species on aquatic ecosystems in Chile. 


\section{Competing interests}

The author declares that he has no competing interests. The author declares that he has no financial competing interests. The author declares that he has no non-financial competing interests.

\section{Acknowledgements}

This study was supported by the Project FONDECYT No. 11130697. I am grateful to anonymous referees for valuable comments to the original manuscript.

Received: 20 June 2014 Accepted: 10 September 2014 Published online: 18 September 2014

\section{References}

Albrecht C, Kroll O, Moreno Terrazas E, Wilke T (2009) Invasion of ancient Lake Titicaca by the globally invasive Physa acuta (Gastropoda: Pulmonata: Hygrophila). Biol Invasions 11:1821-1826

Alonso A, Castro-Diez P (2008) What explains the invading success of the aquatic mud snail Potamopyrgus antipodarum (Hydrobiidae, Mollusca)? Hydrobiologia 614:107-116

Biese WA (1944) Revisión de los moluscos terrestres y de agua dulce provistos de concha de Chile. Parte I, Familia Amnicolidae. Boletín del Museo Nacional de Historia Natural 22:169-190

Biese WA (1947) Revisión de los moluscos terrestres y de agua dulce provistos de concha de Chile. Parte II, Familia Amnicolidae (continuación). Boletín del Museo Nacional de Historia Natural 23:63-77

Bowler PA (1991) The rapid spread of the freshwater hydrobiidae snail Potamopyrgus antipodarum (Gray) in the Middle Snake River, southern Idaho. Proc Desert Fishes Counc 21:173-182

Butkus R, Šidagytė E, Arbačiauskas K (2012) Two morphotypes of the New Zealand mud snail Potamopyrgus antipodarum (J.E. Gray, 1843) (Mollusca: Hydrobiidae) invade Lithuanian Lakes. Aquat Invasions 7(2):211-218

Cheng YW, LeClair LL (2011) A quantitative evaluation of the effect of freezing temperatures on the survival of New Zealand mudsnails (Potamopyrgus antipodarum Gray, 1843), in Olympia Washington's Capitol Lake. Aquat Invasions 6(1):47-54

Collado GA, Méndez MA (2011) Estrategias reproductivas y tipos de desarrollo en especies endémicas del género Heleobia Stimpson, 1865 (Caenogastropoda: Cochliopidae) de Chile. Amici Molluscarum (Número especial), pp 67-71

Collado GA, Méndez MA, Letelier S, Veliz D, Sabando MC (2011a) Morfología peniana y taxonomía del género Heleobia Stimpson, 1865 en Chile junto a una revisión de los ejemplares tipo del Museo Nacional de Historia Natural de Chile. Amici Molluscarum (Número Especial), pp 49-58

Collado GA, Vila I, Méndez MA (2011b) Monophyly, candidate species and vicariance in Biomphalaria snails (Mollusca: Planorbidae) from the Southern Andean Altiplano. Zool Scr 40(6):613-622

Collier KJ, Wilcock RJ, Meredith AS (1998) Influence of substrate type and physico-chemical conditions on macroinvertebrate faunas and biotic indices of some lowland, Waikato, New Zealand streams. N Z J Marine Freshwat Res 32:1-19

Davis GM, Wilke T, Spolsky C, Zhang Y, Xia MY, Rosenberg G (1998) Cytochrome oxidase I-based phylogenetic relationships among the Hydrobiidae, Pomatiopsidae, Rissoidae, and Truncatellidae (Gastropoda: Prosobranchia: Rissoacea). Malacologia 40:251-266

Doello Jurado M (1916) Una nueva variedad de Potamopyrgus: Potamopyrgus scottii Pilsbr. var. delticola, n. var. Physis 2:178

Dorgelo J (1987) Density fluctuations in populations (1982-1986) and biological observations of Potamopyrgus jenkinsi in two trophically differing lakes. Hydrobiol Bull 21:95-110

Duggan IC, Robinson KV, Burns CW, Banks JC, Hogg ID (2012) Identifying invertebrate invasions using morphological and molecular analyses: North American Daphnia 'pulex' in New Zealand fresh waters. Aquat Invasions 7 (4):585-590

Dybdahl MF, Drown DM (2011) The absence of genotypic diversity in a successful parthenogenetic invader. Biol Invasions 13:1663-1672

Facon B, Pointier J-P, Glaubrecht M, Poux C, Jarne P, David P (2003) A molecular phylogeography approach to biological invasions of the New World by parthenogenetic Thiarid snails. Mol Ecol 12:3027-3039

Felsenstein J (1985) Confidence limits on phylogenies: an approach using the bootstrap. Evolution 39:783-791
Folmer O, Black M, Hoeh W, Lutz R, Vrijenhoek R (1994) DNA primers for amplification of mitochondrial cytochrome c oxidase subunit I from diverse metazoan invertebrates. Mol Mar Biol Biotechnol 3:294-299

Gaillard MC (1973) Contribución al conocimiento del género Littoridina Souyele 1852 en Argentina. In: PhD Thesis. Universidad Nacional de La Plata, Argentina

Gaillard MC, de Castellanos ZA (1976) Mollusca, Gasteropoda, Hydrobiidae. Fauna de agua dulce de la República Argentina, Buenos Aires, pp 2-39, 15(2)

Gangloff MM (1998) The New Zealand mud snail in western North America. Aquat Nuis Species 2:25-30

Geller JB, Walton ED, Grosholz ED, Ruiz GM (1997) Cryptic invasions of the crab Carcinus detected by molecular phylogeography. Mol Ecol 6:901-906

Haas F (1938) Neue Binnen-Mollusken aus Nordost-Brasilien. Arch Molluskenkd 70:46-51

Haas F (1949) On fresh water mollusks from the Amazonian Region Anales del Instituto de Biología, Universidad Nacional Autónoma de México. Serie Zoología 20(1-2):301-314

Haas F (1952) South American non-marine shells: further remarks and description. Fieldiana 34(9):107-111

Haase M (2003) Clinal variation in shell morphology of the freshwater gastropod Potamopyrgus antipodarum along two hill-country streams in New Zealand. J Roy Soc New Zealand 33(2):549-560

Haase M (2005) Rapid and convergent evolution of parental care in hydrobiid gastropods from New Zealand. J Evol Biol 18:1076-1086

Hall TA (2001) BioEdit: a user-friendly biological sequence alignment editor and analysis, vers. 5.09. Department of Microbiology, North Carolina State University, Raleigh, NC

Hall RO, Dybdahl MF, Vanderloop MC (2006) Extremely high secondary production of introduced snails in rivers. Ecol Appl 16:1121-1131

Hall RO, Tank J, Dybdahl MF (2003) Exotic snails dominate nitrogen and carbon cycling in a highly productive stream. Front Ecol Environ 1:407-411

Hamada K, Tatara Y, Urabe M (2013) Survey of mitochondrial DNA haplotypes of Potamopyrgus antipodarum (Caenogastropoda: Hydrobiidae) introduced into Japan. Limnology 14(3):223-228

Haynes A, Taylor BJR (1984) Food finding and food preference in Potamopyrgus jenkinsi (E. A. Smith) (Gastropoda: Prosobranchia). Arch Hydrobiol 100:479-491

Haynes A, Taylor BJR, Varley ME (1985) The influence of the mobility of Potamopyrgus jenkinsi (Smith, E.A.) (Prosobranchia: Hydrobiidae) on its spread. Arch Hydrobiol 103:497-508

Hershler R, Liu H-P, Mulvey M (1999) Phylogenetic relationships within the aquatic snail genus Tryonia: implications for biogeography of the North American Southwest. Mol Phyl Evol 13:377-391

Hershler R, Thompson FG (1992) A review of the aquatic gastropod subfamily Cochliopinae (Prosobranchia: Hydrobiidae). Malacol Rev (Supplement) 5:1-140

Jackson D, Jackson D (2009) Registro de Pomacea canaliculata (Lamarck, 1822) (Ampullariidae), molusco exótico para el norte de Chile. Gayana 73(1):40-44

Kerans BL, Dybdahl MF, Gangloff MM, Jannot JE (2005) Potamopyrgus antipodarum: distribution, density, and effects on native macroinvertebrate assemblages in the Greater Yellowstone ecosystem. J N Am Benthol Soc 24 (1):123-138

Letelier S, Ramos A, Huaquín L (2007) Moluscos dulceacuícolas exóticos en Chile. Rev Mex Biodivers 78:9-13

Lima LC, Pereira de Souza C (1990) Ocorrência de um hidrobióide (Mollusca: Mesogastropoda) nos municípios de Pedro Leopoldo e Lagoa Santa, MG, Brasil. Rev Inst Med trop S Paulo 32(2):86-90

Lodge DM, Shrader-Frechette K (2003) Nonindigenous species: ecological explanation, environmental ethics, and public policy. Conserv Biol 17:31-37

Neiman M, Hehman G, Miller JT, Logsdon JM Jr, Taylor DR (2010) Accelerated mutation accumulation in asexual lineages of a freshwater snail. Mol Biol Evol 27:863-954

Ovando XMC, Cuezzo MG (2012) Discovery of an established population of a non-native species of Viviparidae (Caenogastropoda) in Argentina. Molluscan Research 32(3):121-131

Pilsbry HA (1911) Non-marine mollusca of Patagonia. In: Scott WB (ed) Reports of the Princeton University Expedition to Patagonia 1896-1899. Part 5, Zoology. The University of Princeton, Princeton, NJ, USA, pp 513-633

Pilsbry HA (1944) Molluscan fossils from the Río Pachitea and vicinity in eastern Peru. P Acad Nat Sci Phila 96:137-153

Pilsbry HA (1952) Littoridina tenuipes (Couper). Nautilus 66(2):50-54

Poirier J (2013) New Zealand mudsnail surveys at national wildlife refuges within the Lower Columbia River Basin 2012. Columbia River Fisheries Program Office Annual Report. United States Fish and Wildlife Service, pp 1-24 
Ponder WF (1988) Potamopyrgus antipodarum, a molluscan colonizer of Europe and Australia. J Moll Stud 54:271-286

Ponder WF, WilkeT ZW-H, Golding RE, Fukuda H, Mason RAB (2008) Edgbastonia alanwillsi n. gen and n. sp. (Tateinae: Hydrobiidae s.l.: Rissooidea: Caenogastropoda), a snail from an artesian spring group in western Queensland, Australia, convergent with some Asian Amnicolidae. Molluscan Res 28(2):89-106

Pons da Silva MC (2003) Hydrobiidae (Gastropoda: Neotaenioglossa: Rissoidea) da planicie costeira do Rio Grande do Sul, Brasil. Dissertation, Universidade Federal do Rio Grande do Sul, Porto Alegre

Porco D, Decaëns T, Deharveng L, James SW, Skarżyński D, Erséus C, Butt KR, Richard B, Hebert PDN (2013) Biological invasions in soil: DNA barcoding as a monitoring tool in a multiple taxa survey targeting European earthworms and springtails in North America. Biol Invasions 15(4):899-910

Posada D (2008) jModelTest: phylogenetic model averaging. Mol Biol Evol 25:1253-1256

Proctor T, Kerans B, Clancey P, Ryce E, Dybdahl M, Gustafson D, Hall R, Pickett F, Richards D, Waldeck RD, Chapman J, Wiltshire RH, Becker D, Anderson M, Pitman B, Lassuy D, Heimowitz P, Dwyer P, Levri EP (2007) National management and control plan for the New Zealand mudsnail (Potamopyrgus antipodarum). US Fish and Wildlife Service Report. www.anstaskforce.gov/ Documents/NZMS_MgmtControl_Final.pdf Accessed 29 November 2013

Radea C, Louvrou I, Economou-Amilli A (2008) First record of the New Zealand mud snail Potamopyrgus antipodarum J.E. Gray 1843 (Mollusca: Hydrobiidae) in Greece-Notes on its population structure and associated microalgae. Aquat Invasions 3:341-344

Ribi G (1986) Within-lake dispersal of the prosobranch snails, Viviparus ater and Potamopyrgus jenkinsi. Oecologia 69:60-63

Richards DC (2002) The New Zealand mudsnail invades the western United States. Aquat Nuis Species 4:42-44

Richards DC, Cazier LD, Lester GT (2001) Spatial distribution of three snail species, including the invader Potamopyrgus antipodarum, in a freshwater spring. Western North Am Nat 61:375-380

Ronquist F, Huelsenbeck JP (2003) MrBayes 3: Bayesian phylogenetic inference under mixed models. Bioinformatics 19:1572-1574

Shimada K, Urabe M (2003) Comparative ecology of the alien freshwater snail Potamopyrgus antipodarum and the indigenous snail Semisulcospira spp. Venus 62:39-53

Swofford DL (2003) PAUP*: phylogenetic analysis using parsimony (*and other methods). ver. 4. Sinauer Associates, Sunderland

Vareille-Morel C (1983) Les mouvements journaliers du mollusque prosobranche Potamopyrgus jenkinsi Smith, etude sur le terrain et en laboratoire. Haliotis 13:31-34

Wesselingh FP (2000) On relict hydrobiid species in Brazilian Amazonia (Gastropods, Prosobranchia, Hydrobiidae). Basteria 64:129-136

Wetterer JK (2014) A South American fire ant, Solenopsis nr. saevissima, in Guadeloupe, French West Indies. Biol Invasions 16(4):755-758

Wilke T, Davis GM, Gong X, Liu H-X (2000a) Erhaia (Gastropoda: Rissooidea): phylogenetic relationships and the question of Paragonimus coevolution in Asia. Am J Trop Med Hyg 62:453-459

Wilke T, Rolán E, Davis GM (2000b) The mudsnail genus Hydrobia s.s. in the northern Atlantic and western Mediterranean: a phylogenetic hypothesis. Mar Biol 137:827-833

Wilke T, Davis GM, Falniowski A, Giusti F, Bodon M, Szarowska M (2001) Molecular systematics of Hydrobiidae (Mollusca: Gastropoda: Rissooidea): testing monophyly and phylogenetic relationships. P Acad Nat Sci Phila 151:1-21

Wilke T, Haase M, Hershler R, Liu H-P, Misof B, Ponder W (2013) Pushing short DNA fragments to the limit: phylogenetic relationships of 'hydrobioid' gastropods (Caenogastropoda: Rissooidea). Mol Phyl Evol 66(3):715-736

Winnepennickx B, Backeljau T, De Wachter R (1993) Extraction of high molecular weight DNA from molluscs. Trends Genet 9:407

Winterbourn MJ (1970) The New Zealand species of Potamopyrgus (Gastropoda: Hydrobiidae). Malacologia 10:283-321
Winterbourn MJ (1972) Morphological variation of Potamopyrgus jenkinsi (Smith) from England and a comparison with the New Zealand species, Potamopyrgus antipodarum (Gray). Proc Malacol Soc Lond 40:133-145

Zaranko DT, Farara DG, Thompson FG (1997) Another exotic mollusc in the Laurentian Great Lakes: the New Zealand native Potamopyrgus antipodarum (Gray 1843) Gastropoda, Hydrobiidae). Can J Fish Aquat Sci 54:809-814

doi:10.1186/s40555-014-0070-y

Cite this article as: Collado: Out of New Zealand: molecular

identification of the highly invasive freshwater mollusk Potamopyrgus

antipodarum (Gray, 1843) in South America. Zoological Studies 2014 53:70.

\section{Submit your manuscript to a SpringerOpen ${ }^{\odot}$ journal and benefit from:}

- Convenient online submission

Rigorous peer review

- Immediate publication on acceptance

- Open access: articles freely available online

- High visibility within the field

- Retaining the copyright to your article

Submit your next manuscript at $\gg$ springeropen.com 